\title{
THE COMBINATION OF THE IMAGE AND RANGE-BASED 3D ACQUISITION IN ARCHAEOLOGICAL AND ARCHITECTURAL RESEARCH IN THE ROYAL CASTLE IN WARSAW
}

\author{
A. Bocheńska ${ }^{1}$, J. Markiewicz $^{2}$, S. Łapiński $^{3}$ \\ ${ }^{1}$ The Royal Castle in Warsaw, Archaeology Department, Poland - abochenska@zamek-krolewski.pl \\ ${ }^{2}$ Faculty of Geodesy and Cartography, Division of Photogrammetry, Remote Sensing and Spatial Information Systems, Warsaw \\ University of Technology, Warsaw, Poland - jakub.markiewicz@pw.edu.pl, \\ ${ }^{3}$ Faculty of Geodesy and Cartography, Division of Engineering Geodesy and Control Surveying System, Warsaw University of \\ Technology, Warsaw, Poland - slawomir.lapinski@pw.edu.pl
}

\section{Commission II, WG II/8}

KEY WORDS: TLS, SfM, MVS, range-based method, image-based approach, archaeological excavations, Royal Castle in Warsaw.

\begin{abstract}
:
The paper presents archaeological and architectural research in the Royal Castle in Warsaw where a combination of image- and range-based 3D acquisition was applied. The area examined included excavations situated inside the Tower and near its outer western wall. The work was carried out at various periods and in different weather conditions. As part of the measurements, laser scanning was performed (with a Z+F 5006h scanner) and a series of close-range images were taken. It was important to integrate the data acquired to create a comprehensive documentation of archaeological excavations. When data was acquired from TLS together with photogrammetric data (in different measurement periods), the points' displacements were controlled and analysed. The process of orienting and processing the terrestrial images included photographs taken during the inventory of the tower (Canon 5D Mark II) and photographs provided by the Castle's employees (Canon PowerShot G5 X). Agisoft PhotoScan software was used to orient and process the terrestrial images, and LupoScan for the TLS data. In order to integrate the TLS data and the clouds of points from the photographs from the various stages, they were processed into a raster form; our own software (based on the OpenCV library and the Structure-from-Motion method) and LupoScan software were used to interconnect the multi-temporal and multi-sensor data sets. As a result of processing photographs and TLS data, point clouds in an external reference system were obtained. This data was then used to study the thickness of the walls of the Justice Court Tower, to analyse the course of the retaining wall, and to generate the orthoimages necessary for chronological analysis.
\end{abstract}

\section{INTRODUCTION}

During archaeological research it is extremely important to meticulously document the levels which are unearthed. Failing to do this means losing a fundamental source of knowledge, as it is impossible to recreate such data. During excavations, particular layers connected with the object analysed may be irretrievably lost without any further possibility of recreating the primary structure, which may carry data on the historical monument's chronology among others. In so-called urban archaeology, architectural relics have a special place; they are one of the more important sources which testify to the tangible culture of past decades. Conducting accurate inventory of the existing walls in conjunction with the analysis of adjacent layers is thus extremely important. This option is possible thanks to contemporary methods of documentation, both in the area of registration and the further analyses of the data obtained.

The data presented is the result of cooperation between representatives of the humanities and science. The aim of the project was to prepare complete digital documentation of the archaeological excavations carried out within the Royal Castle in Warsaw. The excavations took place near the Justice Court Tower, also known as the Great Tower in the Middle Ages, and which was most probably raised in the third quarter of the 14th century. It is the oldest existing brick edifice which is part of the castle complex. The excavation work carried out in its vicinity

Correasponding author and inside was connected with a conservation program whose objective was to save the unique house marks located on the inside walls of the Prison Cellar, the lowest usable floor of the Tower. However, it should be mentioned that the Royal Castle in Warsaw has almost entirely been reconstructed. The number of relics coming from various historical periods is negligible; the same is true of our knowledge of how the settlement in Warsaw functioned during its most remote periods. Only the foundations and castle cellars, including the Prison Cellar, survived the damage done during the Second World War. The location of the work carried out is extremely important not only because the layers unearthed are part of the original substance, but also, and maybe most of all, because they relate to the beginnings of Warsaw as a city.

The contemporary shape of the southern foot of the Castle, known as the Southern Terrace, is the result of large-scale early modern and contemporary investments and related concepts for landscaping. Especially in the post-war period, the region underwent a complete transformation. Despite substantial interference, during the current works it was possible to reach those layers which had not been damaged, including the layer connected with the raising of the tower, that is, the excavation batch prepared for the foundations.

\section{STATE OF THE ART}

Many research projects require accurate and complete digital documentation of cultural heritage objects and sites for the sake of analysis and interpretation, and in some cases also to aid in 
their restoration. This is particularly important in archaeological research, and so it should be noted that proper registration and documentation of artefacts and sites allow for proper further analysis and interpretation. For that purpose, the image-based (passive methods, i.e. close-range photogrammetry) as well as range-based (active methods, i.e. Terrestrial Laser Scanning TLS) techniques for 3D shape reconstruction are applied (Abbate et al., 2019; Arif and Essa, 2017; Cipriani et al., 2019; Grussenmeyer and Yasmine, 2004; Hatzopoulos et al., 2017; Heras et al., 2019; Markiewicz et al., 2017; Remondino and Elhakim, 2006). The active (range-based modelling) and passive (image-based approach) techniques have their advantages and disadvantages (Gonizzi Barsanti et al., 2013). The main advantages of the image-based approach are: (1) the price of the instrument - cameras cost much less than terrestrial laser scanners, (2) smaller devices in comparison to TLS are more convenient in places which are hard to reach, such as deep excavations, (3) shorter measurement times, in comparison with TLS, (4) independence from the size of the objects examined and the shooting distance - the only limitation is the resultant density of the clouds of points and the GSD of the photographs. On the other hand, there are also disadvantages to the imagebased approach: (1) complete automation is impossible, (2) occlusions on poor and un-textured areas and repetitive structures, (3) dependence on the lighting conditions. The advantages of the TLS (range-based) method include: (1) high accuracy, (2) a large number of points forming a quasicontinuous surface, (3) a high level of automation of measurements, (4) the possibility to record the laser-beam reflectance intensity, which might be used to investigate the properties of the object analysed and (5) the possibility to measure untextured areas, which is the principal advantage. The main disadvantages of the range-based TLS are: (1) the laser beam propagates with distance, which can result in uncertainty regarding the location of the determined point, (2) a problem regarding the intensity of the laser beam reflection (the point is located incorrectly, or not enough fragments of the object being analysed are measured, (3) the mixed-edge problem which causes incorrect measurements of the edges.

Nowadays, because all these methods have their benefits and drawbacks, it is common to integrate both close-range photogrammetry and TLS when carrying out research work concerning cultural heritage and archaeology (e.g. Arif and Essa, 2017; Del Pozo et al., 2017; Drap et al., 2007; Gonizzi Barsanti et al., 2013; Grussenmeyer and Yasmine, 2004; Hatzopoulos et al., 2017; Koistinen, 2004; Markiewicz et al., 2017; Murtiyoso et al., 2017; Nocerino et al., 2012; Remondino and El-hakim, 2006; Sauerbier and Eisenbeiss, 2010). For the purpose of multi-temporal archaeological excavations and research, close-range photogrammetry and TLS data were used.

\section{PERFORMED EXPERIMENT}

To carry out the geodetic and photogrammetric measurements, two measurement methods were used: the close-range terrestrial scanner Z+F 5006h; and close-range images on the Canon 5D Mark II with a low-cost Olympus C-5050Z. The research was divided into five stages (Figure 1). The work was carried out by two teams, a team of surveyors and photogrammetrists from the Warsaw University of Technology, and a team of trained archaeologists from the Royal Castle in Warsaw.

\subsection{Surveying}

The researched area included excavations situated inside the Tower and near its outer western wall (Figure 2) Carrying out deep excavations made it possible to uncover the foundations of the Tower to the level of the foundations and register its primary construction

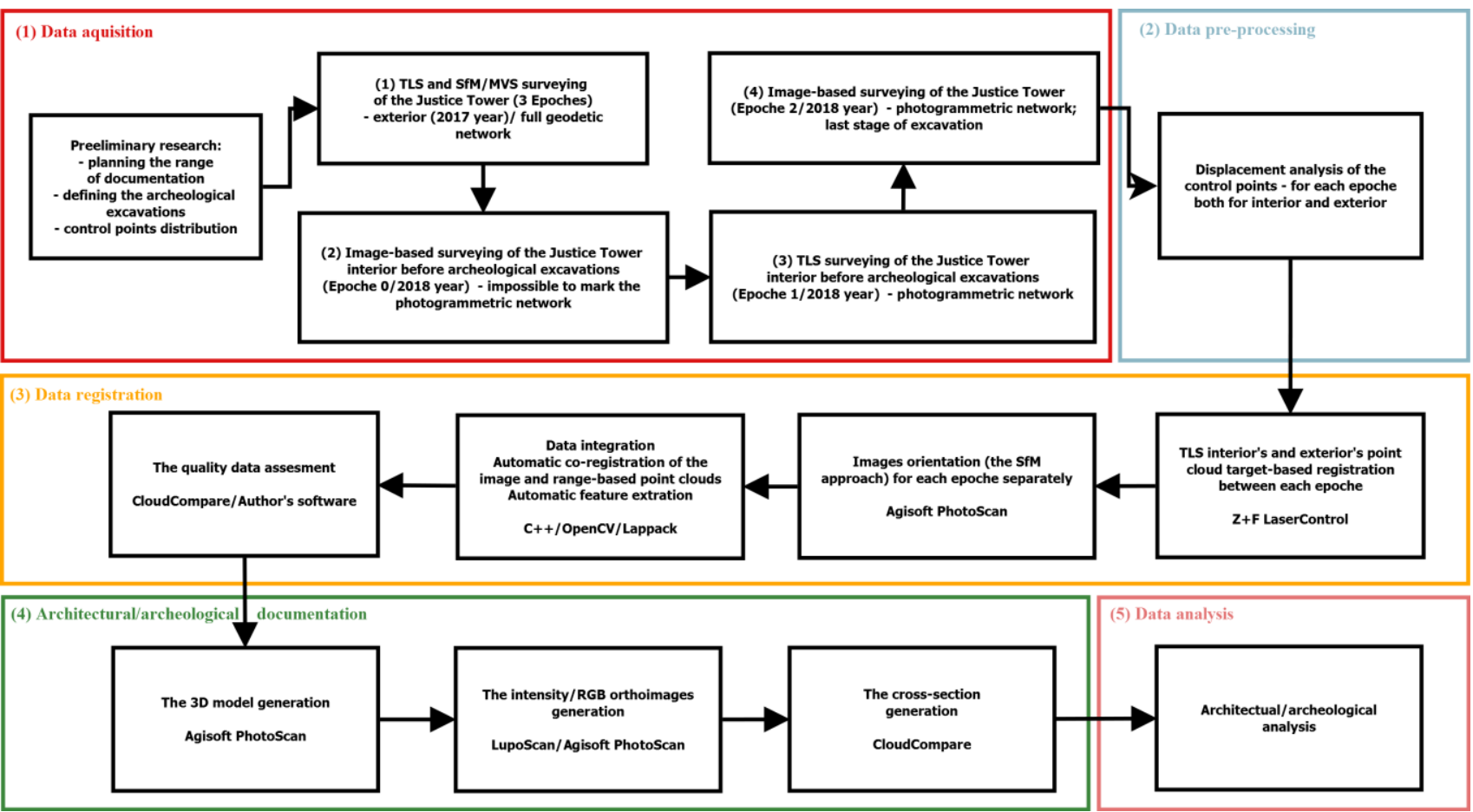

Figure 1. The block diagram of the performed experiment. 

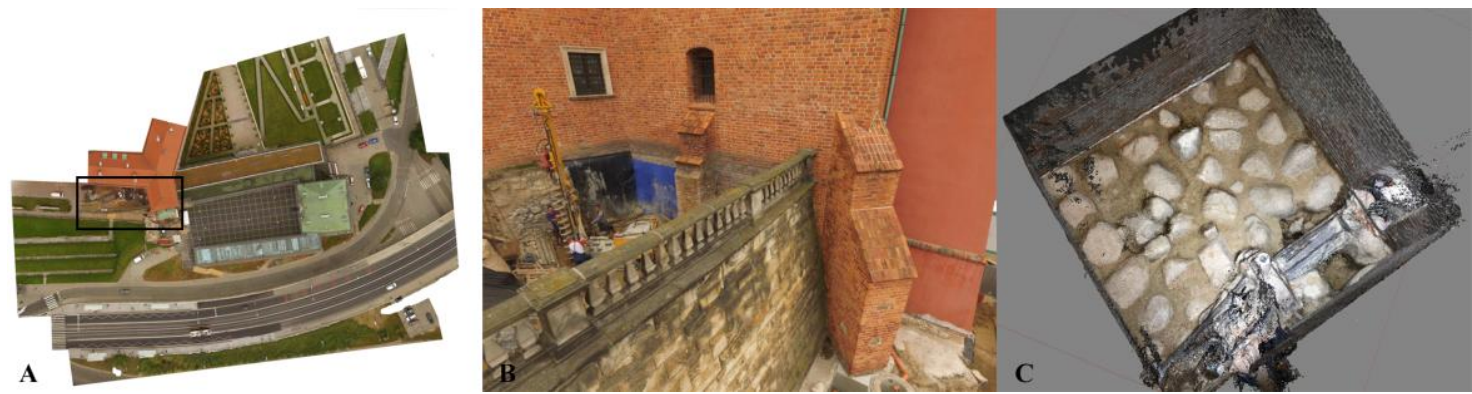

Figure 2. A) A section of a true-orthophotomap with the excavation area marked; B) example of the exterior excavation; C) the analysed interior

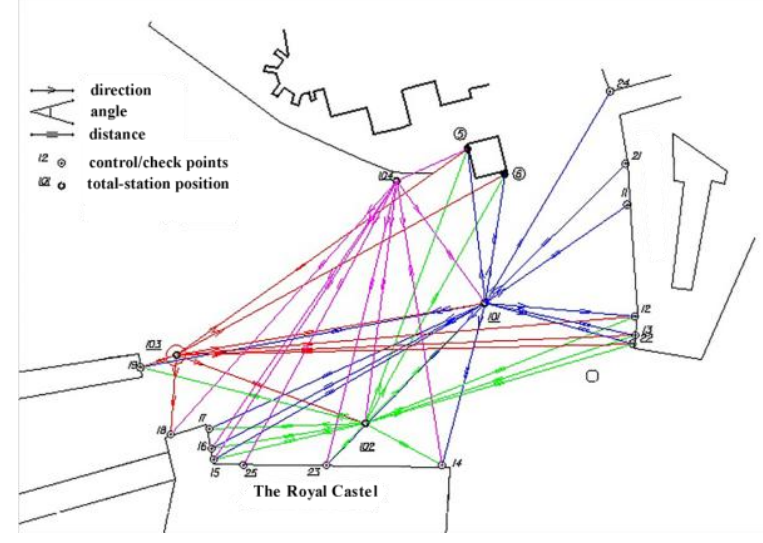

Figure 3. Example of a geodetic network (first-order) used for data registration

Due to the historic character of the building, the registration was done with the non-invasive technique of terrestrial laser scanning, mainly using the $\mathrm{Z}+\mathrm{F} 5006 \mathrm{~h}$ and close-range photogrammetry (Markiewicz et al., 2018). The work was carried out at various periods and in different weather conditions. It was important to integrate the data acquired in order to create a comprehensive profile of the area studied. For that purpose, a geodetic first-order control network was designed and placed (Figure 3).

Measurements were performed using the Leica 1201+ total station which allows measurement of angles of 1 " and reflector distance measurement of $1 \mathrm{~mm}+1.5 \mathrm{ppm}$. Appendix 1 presents the aligned coordinates of the geodetic first-order control points together with the accuracy measurements to determine the position of the points in the adopted local coordinate system $\mathrm{X}$, $\mathrm{Y}, \mathrm{H}$. Because of construction work (deep excavations), it was necessary to monitoring (measurement of displacements) the geodetic control points in time. The geodetic first-order control points were the primary and unified reference system for establishing a photogrammetric second-order network, which was an important element of the relative orientation of different types of data.

Moreover, archaeological and inventory work was carried out inside the Justice Court Tower. In order to set the coordinates of the points located there, the coordinates of the positions located between the outer part of the building and the inside of the Tower were transformed in the adopted datum connected with the outer vicinity of the Royal Castle. The positions created a hanging traverse. A three-tripod method consisting in placing three stations, one instrument and two prisms, was used as a measuring method. Measurements were taken between the stands, but their relative location was not changed. This allowed for more precise measurement results and helped minimise the possibility of errors. The coordinates from the outer reference system were transferred to the inside of the tower where a photogrammetric network was set up. The $\mathrm{X}$ and $\mathrm{Y}$ coordinates of the photogrammetric network were calculated with the polar method, whereas the $\mathrm{H}$ coordinate was calculated with the trigonometric levelling method. The horizontal, vertical angles and oblique distances were observed in two series in order to eliminate the possibility of so-called gross errors in observations. The observations taken for the calculations were averaged from two measurements. This data was used for the TLS data (Figure 4) and image registration.

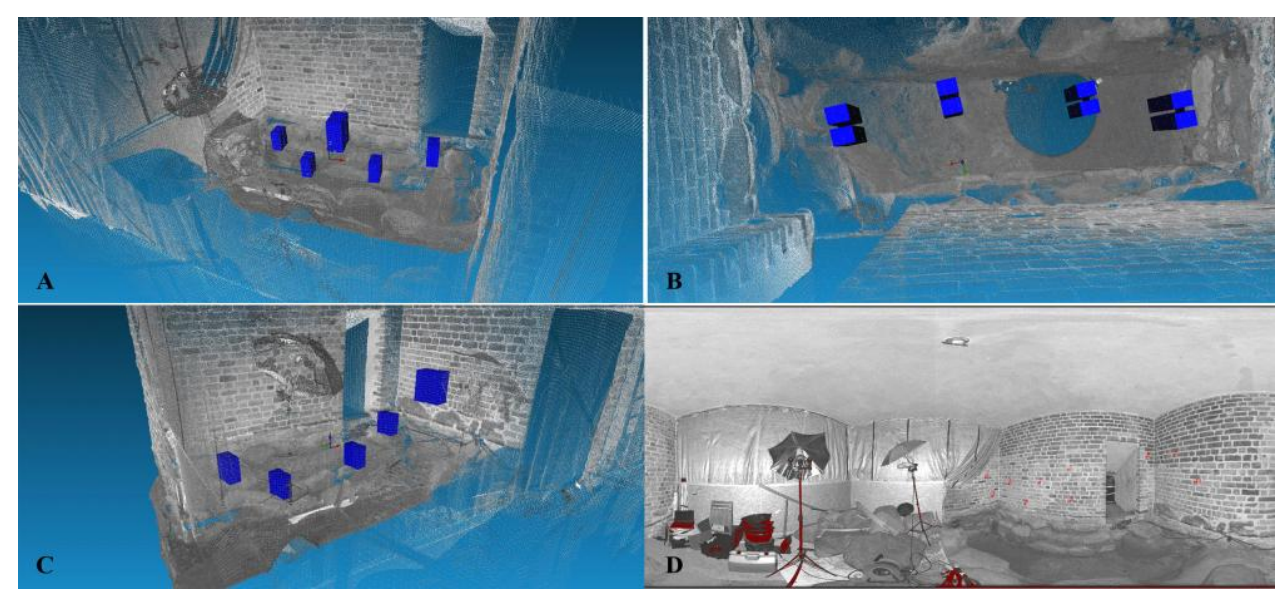

Figure 4. The example locations of scanner stations (A-C) with the control points marked in the spherical image (D). 


\begin{tabular}{|c|c|c|c|c|c|c|}
\hline \multicolumn{2}{|c|}{ Images } & \multicolumn{5}{c|}{ TLS } \\
\hline No. of images & 380 & Station & $\begin{array}{c}\text { No. of control } \\
\text { points }\end{array}$ & $\begin{array}{c}\text { No. of } \\
\text { checkpoints }\end{array}$ & $\begin{array}{c}\text { RMSE on control } \\
\text { points [mm] }\end{array}$ & $\begin{array}{c}\text { RMSE on check } \\
\text { points [mm] }\end{array}$ \\
\hline $\begin{array}{c}\text { RMSE reprojection error } \\
\text { on control points }\end{array}$ & 0.8 & 1 & 4 & 5 & 1.3 & 1.0 \\
\hline $\begin{array}{c}\text { RMSE reprojection error } \\
\text { on control points }\end{array}$ & 0.4 & 2 & 4 & 4 & 1.4 & 1.9 \\
\hline RMSE on control points & $3.2 \mathrm{~mm}$ & 3 & 3 & 2 & 1.5 & 1.8 \\
\hline RMSE on check points & $3.2 \mathrm{~mm}$ & 4 & 4 & 4 & 1.3 & 0.9 \\
\cline { 2 - 7 } \\
\hline
\end{tabular}

Table 1. The results of the processing of TLS data and photographs with the Structure-from-Motion method

\subsection{Image and range-base measurements}

The process of orientation and processing the terrestrial images included photographs taken during the inventory of the boulders stabilizing the construction of the tower (set I - 275 photographs taken with Canon 5D Mark II) and photographs provided by the castle's employees (set II - 380 photographs taken with Canon PowerShot G5 X, Figure 5). The Agisoft PhotoScan software was used to orient and process the terrestrial images. Table 1 presents the results of the alignment of the TLS data and the photographs.

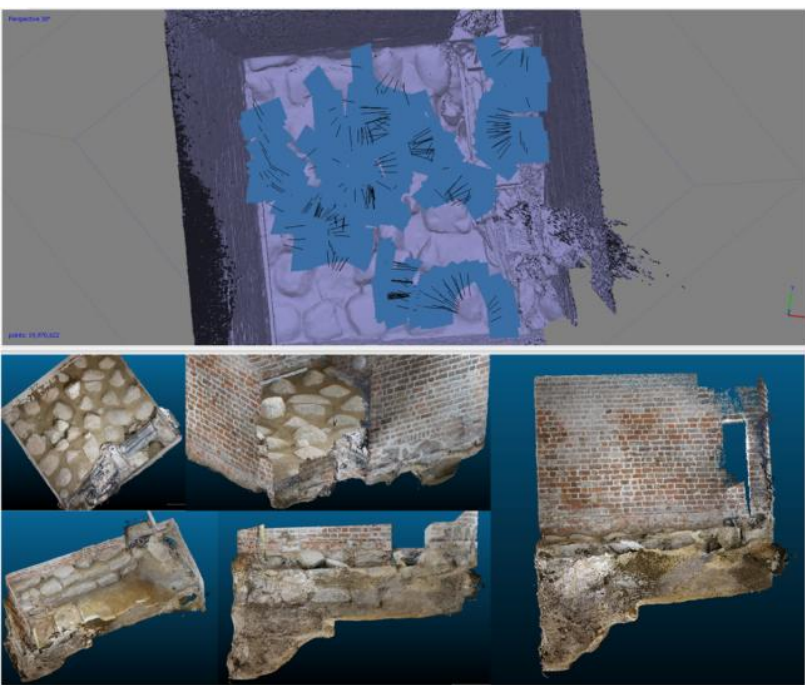

Figure 5. The example of images location and generated point clouds

During the first stage, the orientation of the first set of photographs was carried out on the basis of the photogrammetric network. This allowed them to be incorporated into the outer reference system and to generate 3D models. These oriented and fitted photographs were used as references for the second set of photographs where check and control points were not placed. The process of align the images from the second set consisted in detecting the common points in both sets and common data processing. In order to integrate the clouds of points from the photographs taken at various stages, they were processed into a raster form; we used our own software based on the OpenCV library and the Structure-fromMotion method. The detailed description of the way the cloud of points was processed can be found in Markiewicz and Zawieska (2019), among others. Figure 6 shows an example of detecting binding points on two clouds of points which have been converted into a raster form.

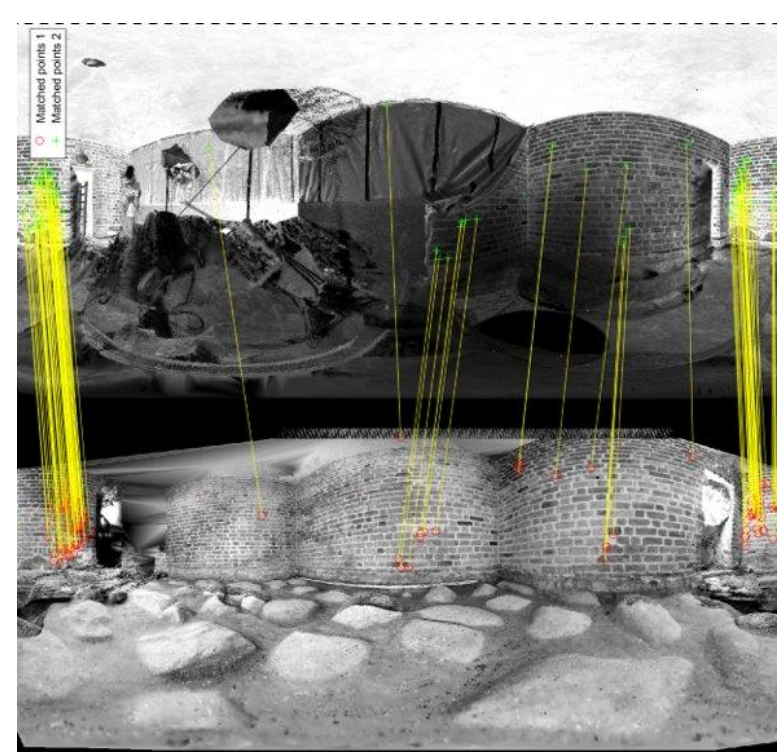

Figure 6 . The example of images location and generated point clouds

Because it was not possible to assess the accuracy of the process of orienting the marked check and control points of the photographs from the second set, it was decided to analyse the distances between clouds of points on the selected test sections.

The analysis of the histograms of deviations between clouds of points shows that they roughly adopt a Gaussian distribution (normal distribution) and didnot exceed $5 \mathrm{~mm}$, which proves that the orientation of terrestrial photographs from the first stage was carried out correctly (Figure 7).

\section{RESULT AND ANALYSIS}

As a result of processing and orienting photographs and TLS data, clouds of points in an external coordinate system were obtained. This data was used to study the thickness of the walls of the Justice Court Tower (Figure 9), to analyse the course of the retaining wall, and to generate the orthoimages necessary for chronological analysis (Figure 8). The information obtained allowed us to verify the landform where the Tower had been raised and gave the opportunity to accurately determine the thickness of the walls. 

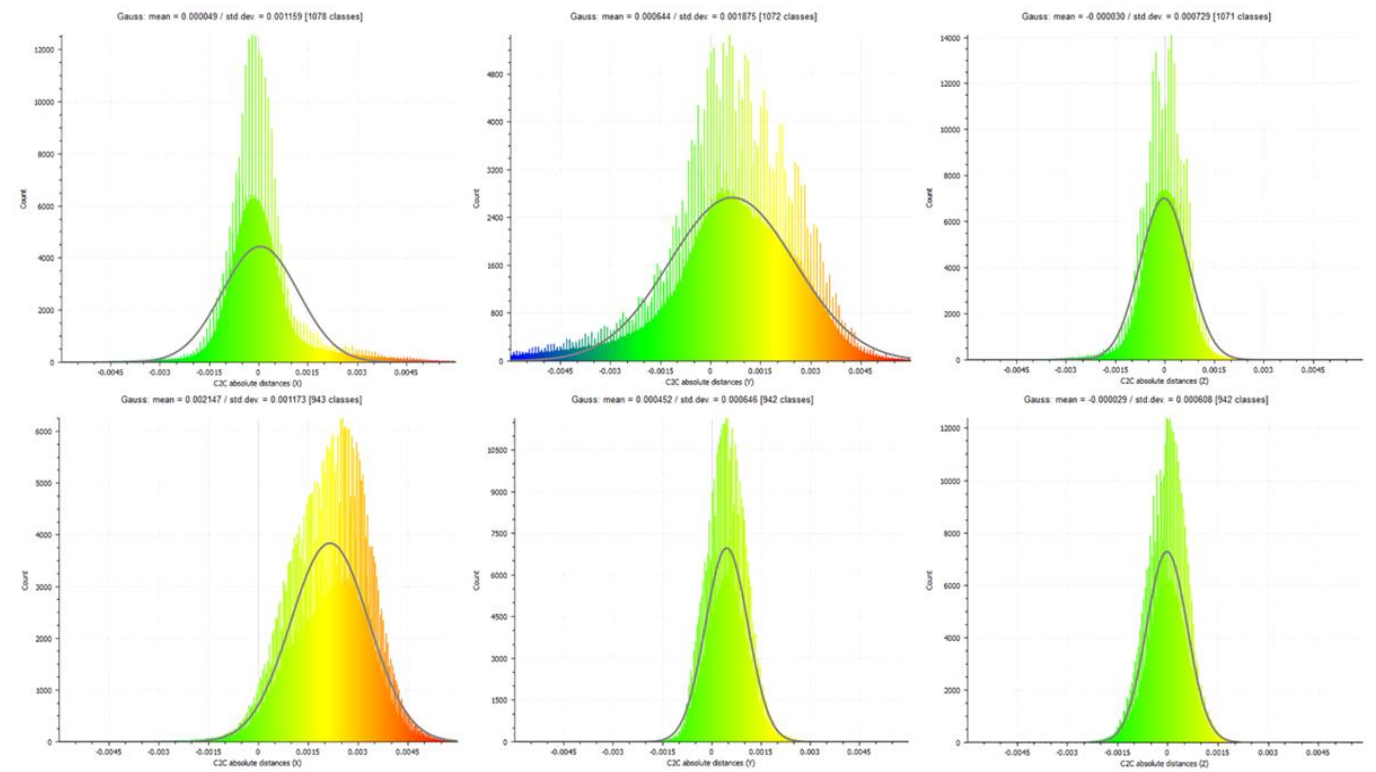

Figure 7. Histograms of deviations on test sections between clouds of points created during stages I and II

The full profile of the station (Figure 9) allowed us to trace the sequence of the construction process, starting from preparatory phases to the full project implementation. A deep excavation for the foundations of the western wall of the Tower can be seen in the attached cross-section. Its upper parts were offset by contemporary investments; the original level of the fill layers is marked by the blue arrow. The eastern side of wall A reveals a stepped construction of wall N's foundations which were built on the slope of the hill constituting the base of the building. Consequently, the stone base of the eastern wall was reduced to $1 \mathrm{~m}$ in height. The difference in the levels of the foundation of opposite walls equals approximately 2.5 metres.

The work in this place, on the western side of the Justice Court Tower, was important for one more reason. It provided the opportunity to verify the theory which had been devised after the discoveries in the adjacent courtyard of the Tin-Roofed Palace, where excavations took place in 2004-2007. These resulted in unearthing the relics of two defensive systems, a wooden and earthen rampart and its parallel stone and brick wall. Both constructions were erected on a northeast-southwest axis. Based on the stratigraphic observation and analyses of the position of both structures relative to each other, Michał Sekuła drew the conclusion that both the wall and the rampart were not in situ, and their location at the moment of their discovery was the result of a geological catastrophe which had taken place in the past. The landslide occurred from the area adjacent to the current Justice Court Tower. According to Sekuła, in the primary configuration, the tower and the wooden and earthen rampart co-existed (Sekuła, 2011, 2007), and thus created a uniform defensive system.

However, from the preliminary analysis of the latest research it does not appear that the wooden and earthen rampart moved. It seems that during the catastrophe which undoubtedly took place, only a large section of the brick and stone wall was damaged as it slid down and crushed the wooden defences (Figure 10). However, before the wall was built the Tower had been a free-standing construction which did not have any wooden strengthening. During the excavations on the western side of the Tower, no traces of existence of any wooden constructions connected with the Tower were found. Only the above-mentioned large construction excavation prepared for the foundations was recorded.

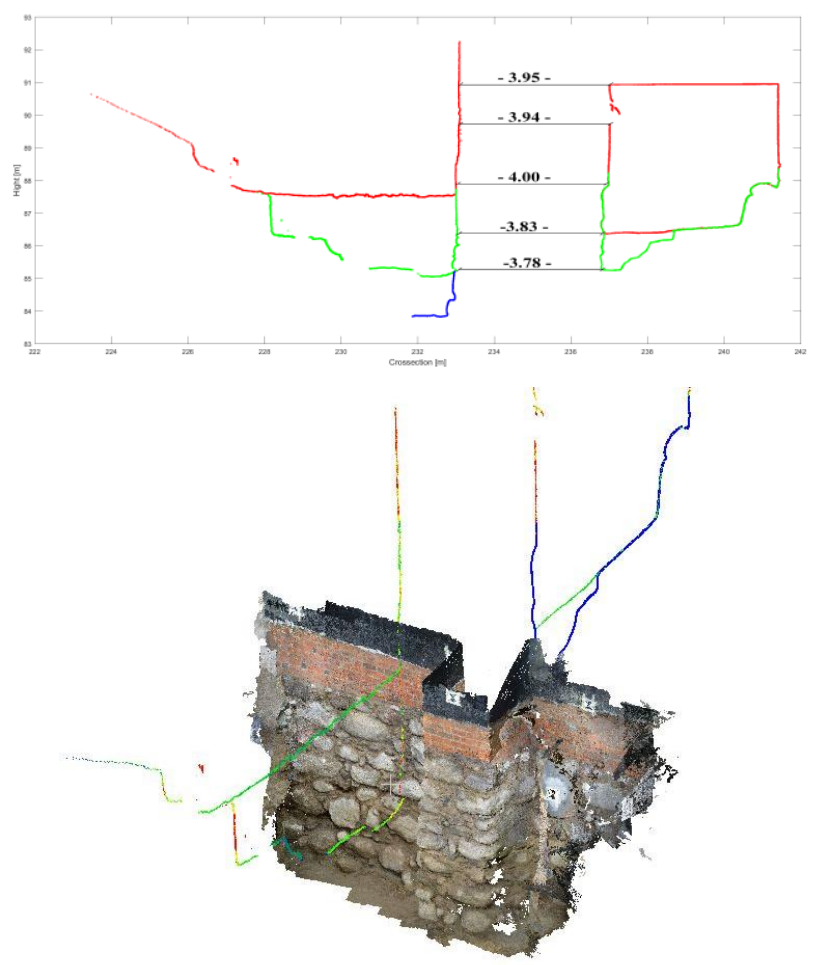

Figure 8. Example cross-section with marked measurements 
The whole documentation allowed an extended architectural and archeological analysis to be performed.

A comprehensive image of the object examined was obtained, thanks to adjusting the method of documentation to the current weather conditions during the work in progress, together with the possibility to integrate the data. The full profile of the station allowed us to trace the sequence of the construction process, starting from preparatory phases to the full project implementation. The detailed analysis of the levels documented made it possible to verify the theories adopted, as well as the results of previous research. The controversial post-war reconstruction of the Prison Cellar may serve as an example.

Analysis of the bricks from the Prison Cellar's northern wall showed that it had been decided to completely rebuild the wall, despite the original wall being preserved to at least threequarters of its height. During the excavations, the wall was entirely dismantled and then built again with the original material. The gaps were filled with bricks from other periods. Unfortunately, this fact had not been recorded, and until the latest excavations it had been assumed that the wall had remained intact to the present day. Rebuilding was also confirmed by the analysis of the location of the bricks' engraved characters, which had been inventoried before the reconstruction. Having compared the photographs, it turned out that some of them had been displaced. Rebuilding using nonoriginal bricks was also confirmed by the analysis of the reflection intensity.

\section{REFERENCES}

Abbate, E., Sammartano, G., Spanò, A., 2019. Prospective upon multi-source urban scale data for $3 \mathrm{~d}$ documentation and monitoring of urban legacies. ISPRS Annals of the Photogrammetry, Remote Sensing and Spatial Information Sciences. doi:10.5194/isprs-Archives-XLII-2-W11-11-2019.

Arif, R., Essa, K., 2017: Evolving techniques of documentation of a world heritage site in Lahore. International Archives of the Photogrammetry, Remote Sensing and Spatial Information Sciences - ISPRS Archives. doi:10.5194/isprs-archives-XLII-2W5-33-2017.

Cipriani, L., Bertacchi, S., Bertacchi, G., 2019. An optimised workflow for the interactive experience with cultural heritage through reality-based 3d models: Cases study in archaeological and urban complexes. ISPRS Annals of the Photogrammetry, Remote Sensing and Spatial Information Sciences. doi:10.5194/isprs-Archives-XLII-2-W11-427-2019.

Del Pozo, S., Rodríguez-Gonzálvez, P., Sánchez-Aparicio, L.J., Muñoz-Nieto, A., Hernández-López, D., Felipe-García, B., González-Aguilera, D., 2017: Multispectral imaging in cultural heritage conservation. International Archives of the Photogrammetry, Remote Sensing and Spatial Information Sciences - ISPRS Archives. doi:10.5194/isprs-archives-XLII-2W5-155-2017.

Drap, P., Durand, A., Nedir, M., Seinturier, J., Papini, O., Gabrielli, R., Peloso, D., Kadobayashi, R., Gaillard, G., Chapman, P., Viant, W., Vannini, G., Nucciotti, M., 2007. Photogrammetry and Archaeological Knowledge: Toward a 3D Information System Dedicated to Medieval Archaeology: A Case Study of Shawback Castle in Jordan. Int. Arch. Photogramm. Remote Sens. Spat. Inf. Sci.

Gonizzi Barsanti, S., Remondino, F., Visintini, D., 2013. 3D surveying and modeling of archaeological sites - Some critical issues-. ISPRS Annals of the Photogrammetry, Remote Sensing and Spatial Information Sciences. doi:10.5194/isprsannals-II-5W1-145-2013.

Grussenmeyer, P., Yasmine, J., 2004. Photogrammetry for the Preparation of Archaeological Excavation. A 3D Restitution According to Modern and Archive Images of Beaufort Castle landscape (Lebanon). Int. Arch. Photogramm. Remote Sens.

Hatzopoulos, J.N., Stefanakis, D., Georgopoulos, A., Tapinaki, S., Pantelis, V., Liritzis, I., 2017. Use of various surveying technologies to 3D digital mapping and modelling of cultural heritage structures for maintenance and restoration purposes: The Tholos in Delphi, Greece. Mediterr. Archaeol. Archaeom. doi:10.5281/zenodo.1048937.

Heras, V., Sinchi, E., Briones, J., Lupercio, L., 2019. Urban heritage monitoring, using image processing techniques and data collection with terrestrial laser scanner (tls), case study cuenca-Ecuador. ISPRS Annals of the Photogrammetry, Remote Sensing and Spatial Information Sciences. doi:10.5194/isprsArchives-XLII-2-W11-609-2019.

Kąsinowski, A., 1962. Warszawa - Zamek Królewski. Badania architektoniczne środkowej części skrzydła wschodniego wraz z podsumowaniem badan architektonicznych z lat 1960-62. Arch. R. Castle Warsaw, 15-27.

Koistinen, K., 2004. Multitemporal Archaeological Imagery to Model the Progress of Excavation, in: Orhan Altan, M. (Ed.), XXth ISPRS Congress, Istanbul, Turkey, 12.-23.7.2004. ISPRS, pp. 1006-1011.

Markiewicz, J., Zawieska, D., 2019. The Influence of the Cartographic Transformation of TLS Data on the Quality of the Automatic Registration. Appl. Sci. doi:10.3390/app9030509.

Markiewicz, J., Zawieska, D., Bocheńska, A., Tobiasz, A., Łapiński, S., 2018: The multitemporal photogrammetric data in archaeological and architectural research in the royal castle in Warsaw - First results. International Archives of the Photogrammetry, Remote Sensing and Spatial Information Sciences - ISPRS Archives. doi:10.5194/isprs-archives-XLII-2675-2018.

Markiewicz, J., Zawieska, D., Podlasiak, P., 2017: Comparing multi-source photogrammetric data during the examination of verticality in a Monumental tower. International Archives of the Photogrammetry, Remote Sensing and Spatial Information Sciences - ISPRS Archives. doi:10.5194/isprs-archives-XLII-2W3-475-2017.

Murtiyoso, A., Koehl, M., Grussenmeyer, P., Freville, T., 2017. Acquisition And Processing Protocols For Uav Images: 3d Modeling Of Historical Buildings Using Photogrammetry. ISPRS Annals of the Photogrammetry, Remote Sensing and Spatial Information Sciences. doi:10.5194/isprs-annals-IV-2W2-163-2017.

Nocerino, E., Menna, F., Menna, F., 2012: Multi-Temporal Analysis of Landscapes and Urban Areas. ISPRS - Int. Arch. Photogramm. Remote Sens. Spat. Inf. Sci. doi:10.5194/isprsarchives-xxxix-b4-85-2012.

Remondino, F., El-hakim, S., 2006. Image-based 3D modelling: A review. Photogramm. Rec. doi:10.1111/j.14779730.2006.00383.x. 
Sauerbier, M., Eisenbeiss, H., 2010. Uavs for the Documentation of Archaeological Excavations. Proc. Isprs Comm. V Mid-Term Symp. Close Range Image Meas. Tech.

Sekuła, M., 2011. Warszawska siedziba książęca w świetle najnowszych badań. Z Otchłani Wieków pismo poświęcone pradziejom Polski. 66, 22-38.

Sekuła, M., 2007. Relikty umocnień obronnych warszawskiej siedziby książęcej, odkryte na dziedzińcu pałacu Pod Blachą. Castle's Chron. 1-2, 91-115.

Skórewicz, K., 1924. Zamek Królewski w Warszawie na tle badań architektonicznych $i$ archiwalnych 1915-1924. „Architekt", Kraków.

APPENDIX 1. The aligned coordinates and the position determination accuracies (X, Y, Z) of the first-order control points.

\begin{tabular}{|c|c|c|c|c|c|c|}
\hline \multicolumn{7}{|c|}{ Aligned coordinates XYZ } \\
\hline No & $\mathrm{X}[\mathrm{m}]$ & $\mathrm{Y}[\mathrm{m}]$ & $\mathrm{H}[\mathrm{m}]$ & $\mathrm{mX}[\mathrm{m}]$ & $\mathrm{mY}[\mathrm{m}]$ & $\mathrm{mH}[\mathrm{m}]$ \\
\hline 8 & 45.8531 & 148.1919 & 99.3468 & 0.0005 & 0.0005 & 0.0008 \\
\hline 11 & 61.215 & 100.3655 & 99.6349 & 0.0007 & 0.0009 & 0.0008 \\
\hline 14 & 135.3446 & 160.9539 & 95.4759 & 0.0004 & 0.0003 & 0.0006 \\
\hline 15 & 130.9312 & 232.5959 & 95.2355 & 0.0008 & 0.0006 & 0.0007 \\
\hline 16 & 130.6286 & 232.6624 & 94.7653 & 0.0008 & 0.0006 & 0.0007 \\
\hline 17 & 123.6288 & 234.1956 & 95.0493 & 0.0008 & 0.0006 & 0.0007 \\
\hline 18 & 118.3146 & 244.5031 & 87.4102 & 0.0011 & 0.0004 & 0.0007 \\
\hline 19 & 103.5141 & 253.0822 & 87.3963 & 0.0009 & 0.0005 & 0.0007 \\
\hline 21 & 40.8374 & 101.4414 & 101.1483 & 0.0008 & 0.0009 & 0.0009 \\
\hline 22 & 100.0257 & 100.0104 & 100.0001 & 0.0004 & 0.0004 & 0.0006 \\
\hline 23 & 132.9302 & 204.1054 & 95.5136 & 0.0008 & 0.0005 & 0.0007 \\
\hline 24 & -12.4138 & 106.5388 & 100.0806 & 0.0007 & 0.0002 & 0.0009 \\
\hline 25 & 131.8381 & 222.0548 & 95.6405 & 0.0008 & 0.0005 & 0.0007 \\
\hline 101 & 82.1488 & 150.0136 & 95.8888 & 0.0004 & 0.0003 & 0.0005 \\
\hline 102 & 45.7316 & 175.7519 & 92.2480 & 0.0005 & 0.0005 & 0.0007 \\
\hline 103 & 100.2609 & 248.1243 & 84.9912 & 0.0009 & 0.0004 & 0.0007 \\
\hline 104 & 107.9068 & 190.3853 & 90.0508 & 0.0006 & 0.0003 & 0.0006 \\
\hline
\end{tabular}

